\title{
Erratum: Transcription and replication result in distinct epigenetic marks following repression of early gene expression
}

\section{Barry Milavetz ${ }^{1}$, Les Kallestad ${ }^{1}$, Emily Woods ${ }^{1}$, Kendra Christensen $^{1}$, Amanda Gefroh ${ }^{1}$ and Lata Balakrishnan²}

${ }^{1}$ Department of Biochemistry and Molecular Biology, University of North Dakota School of Medicine and Health Sciences, Grand Forks, ND, USA

2 Department of Biochemistry and Biophysics, University of Rochester School of Medicine and Dentistry, Rochester, NY, USA

*Correspondence: barry.milavetz@med.und.edu

\section{Edited by:}

Rui Henrique, Portuguese Oncology Institute Porto, Portugal

Keywords: viral epigenetics, SV40, transcription, replication origin, H3K9, H3K4

\section{An erratum on}

Transcription and replication result in distinct epigenetic marks following repression of early gene expression by Kallestad, L., Woods, E., Christensen, K., Gefroh, A., Balakrishnan, L., Milavetz, B. (2013). Front. Genet. 4:140. doi: 10.3389/fgene.2013.00140

In reviewing our recent publication, "Transcription and replication result in distinct epigenetic marks following repression of early gene expression" published 30 July 2013, we noted that there was an error in Figure 3. Apparently between the original submission and our review of the proofs we did not notice that the correct Figure 3 graphic had been replaced by a copy of the graphic in Figure 2B. We regret the error.

Received: 03 November 2013; accepted: 11 November 2013; published online: 02 December 2013.

Citation: Milavetz B, Kallestad L, Woods E, Christensen K, Gefroh A and Balakrishnan L (2013) Erratum:
Transcription and replication result in distinct epigenetic marks following repression of early gene expression. Front. Genet. 4:259. doi: 10.3389/fgene.2013.00259

This article was submitted to Epigenomics and Epigenetics, a section of the journal Frontiers in Genetics.

Copyright (c) 2013 Milavetz, Kallestad, Woods, Christensen, Gefroh and Balakrishnan. This is an open-access article distributed under the terms of the Creative Commons Attribution License (CC BY). The use, distribution or reproduction in other forums is permitted, provided the original author(s) or licensor are credited and that the original publication in this journal is cited, in accordance with accepted academic practice. No use, distribution or reproduction is permitted which does not comply with these terms.

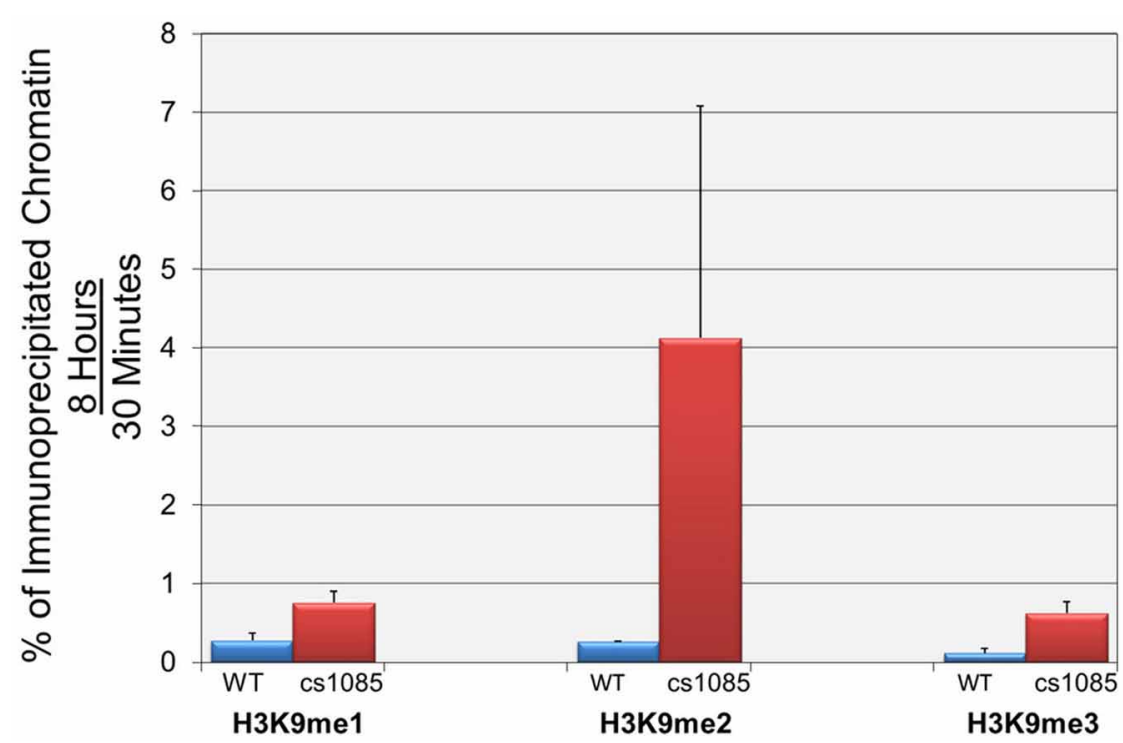

FIGURE 3 | H3K9me2 is significantly increased during active early transcription in the site I deletion mutant cs1085. Wild-type and cs1085 SV40 minichromosomes were isolated from appropriately infected cells at $30 \mathrm{~min}$ and $8 \mathrm{~h}$ post-infection. Isolated minichromosomes were subjected to ChIP analyses with antibodies against $\mathrm{H} 3 \mathrm{~K} 9 \mathrm{me} 1, \mathrm{H} 3 \mathrm{~K} 9 \mathrm{me} 2$, and $\mathrm{H} 3 \mathrm{~K} 9 \mathrm{me}$, and the percentage of input minichromosomes containing each form of methylated $\mathrm{H} 3$ determined by real-time PCR. The results are displayed as the ratio of the percentage of minichromosomes isolated at $8 \mathrm{~h}$ which contain a particular modification divided by the percentage of minichromosomes isolated at $30 \mathrm{~min}$ which contain the same modification. Ratios greater than 1 indicate that a modification is increasing during the period from $30 \mathrm{~min}$ to $8 \mathrm{~h}$, while a ratio less than 1 indicates that the modification is decreasing during this period of infection. All analyses were performed a minimum of three times using different preparations of SV40 minichromosomes. 